\title{
Parental background, early scholastic ability, the allocation into secondary school tracks and language skills at the age of 15 years in a highly differentiated system: a test of the contradictions between a two- or three-level approach
}

Citation for published version (APA):

Dronkers, J. (2014). Parental background, early scholastic ability, the allocation into secondary school tracks and language skills at the age of 15 years in a highly differentiated system: a test of the contradictions between a two- or three-level approach. ROA. ROA Technical Reports No. 001 https://doi.org/10.26481/umarot.2014001

Document status and date:

Published: 01/01/2014

DOI:

10.26481/umarot.2014001

Document Version:

Publisher's PDF, also known as Version of record

Please check the document version of this publication:

- A submitted manuscript is the version of the article upon submission and before peer-review. There can be important differences between the submitted version and the official published version of record. People interested in the research are advised to contact the author for the final version of the publication, or visit the DOI to the publisher's website.

- The final author version and the galley proof are versions of the publication after peer review.

- The final published version features the final layout of the paper including the volume, issue and page numbers.

Link to publication

\footnotetext{
General rights rights.

- You may freely distribute the URL identifying the publication in the public portal. please follow below link for the End User Agreement:

www.umlib.nl/taverne-license

Take down policy

If you believe that this document breaches copyright please contact us at:

repository@maastrichtuniversity.nl

providing details and we will investigate your claim.
}

Copyright and moral rights for the publications made accessible in the public portal are retained by the authors and/or other copyright owners and it is a condition of accessing publications that users recognise and abide by the legal requirements associated with these

- Users may download and print one copy of any publication from the public portal for the purpose of private study or research.

- You may not further distribute the material or use it for any profit-making activity or commercial gain

If the publication is distributed under the terms of Article 25fa of the Dutch Copyright Act, indicated by the "Taverne" license above,

Download date: 26 Apr. 2023 
Maastricht University

Research Centre for Education and the Labour Market | ROA

Parental background, early scholastic ability, the allocation into secondary tracks and language skills at the age of 15 years in a highly differentiated system: a test of the contradictions between a two- or three-level approach

Jaap Dronkers

\section{ROA Technical Report}

ROA-TR-2014/1

Research Centre for Education and the Labour Market

Maastricht University

P.O. Box 616, 6200 MD Maastricht, The Netherlands

$\mathrm{T}+31433883647 \mathrm{~F}+31433884914$

secretary-roa-sbe@maastrichtuniversity.nl

www.roa.nl 


\section{Parental background, early scholastic ability, the allocation into secondary school tracks and language skills at the age of $\mathbf{1 5}$ years in a highly differentiated system: a test of the contradictions between a two- or three-level approach}

Jaap Dronkers

ROA-TR-2014/1

January 2014

Research Centre for Education and the Labour Market Maastricht University

P.O. Box 616, 6200 MD Maastricht, The Netherlands

$\mathrm{T}+31433883647 \mathrm{~F}+31433884914$

secretary-roa-sbe@maastrichtuniversity.nl www.roa.nl 


\title{
Parental background, early scholastic ability, the allocation into secondary school tracks and language skills at the age of 15 years in a highly differentiated system: a test of the contradictions between a two- or three-level approach. ${ }^{1}$
}

\author{
Version 31 December 2013
}

Jaap Dronkers

Maastricht University

E-mail: j.dronkers@maastrichtuniversity.nl

Personal homepage: http://www.roa.unimaas.nl/cv/dronkers/nw dronkers.htm

\section{Introduction}

Recently Dunne (2010) and Dronkers, van der Velden \& Dunne (2011) introduced a threelevel model: countries, schools, and students. They showed that school characteristics like socioeconomic composition and ethnic diversity have substantial effects on achievement levels and also affect the relation between parental background and achievement. Moreover, these school characteristics seem to mediate some of the effects of educational system characteristics found earlier (see Figure 1). However their results contradict very much the consensus about the effects of educational systems on outcomes and inequality, which are exclusively based on a two-level model: countries and students. The most important authors are Hanushek and Wößmann (2006), Schütz, Ursprung and Wößmann (2008), Wößmann, Lüdemann, Schütz and West (2009) and Hanushek and Wößmann (2012). Esser (forth coming) discussed rightfully extensively the possible explanations of the different outcomes of the Hanushek \& Wössmann approach and the Dronkers, van der Velden \& Dunne puzzle.

A main problem of these and related analyses (Bol, Witschge, Werfhorst \& Dronkers, forthcoming; Korthals, 2013) is that the used data are cross-sectional (mostly PISA data, which allow variance between the level of differentiation of educational systems) lack a measurement of scholastic ability before selection into secondary schools. This makes it impossible to distinguish between SES- and ability school-composition (which is by definition more important in early differentiating educational systems, due to selection into different school types), and the sorting of the pupils based on their parental background and scholastic ability before sorting at the entrance of secondary education. Esser (forthcoming) discussed rightfully extensively this problem (see Figure 2).

In this research note I try to solve this problem partly with Dutch longitudinal data (VOCL 1989), which also contains a measurement of scholastic ability of the pupils before entering secondary education. It contains also a school-ID of the secondary schools, thus allows computing SES- and ability school-composition of all secondary schools. I can also distinguish between various school-types in the first years of Dutch secondary education, running from non-selective (comprehensive) to highly selective (Gymnasium).

The aim is threefold: 1 . To establish whether the relation between parental education and early scholastic ability differs in more or less selective school types. Based on Dunne (2010) and Dronkers, van der Velden \& Dunne (2011) we expect that the relation between parental education and early scholastic ability would be stronger in the less selective school types en weaker in the more selective school types. 2 . To establish whether the strength of the effect of parental education on getting a recommendation for a school type and on attending a

\footnotetext{
${ }^{1}$ I thank Hartmut Esser who inspired me to write this research note.
} 
school type in the first or second year is smaller than the strength of early scholastic ability. Based on Dunne (2010) and Dronkers, van der Velden \& Dunne (2011) we expect that the strength of parental education is substantially smaller than that of early scholastic ability, and especially for more selective school types. 3. To establish whether parental education and socio-economic school composition are still related to the language score in the third year (pupils are around 15 years old, just like the pupils in PISA), in relation to the completeness of the allocation into various schooltypes. Based on Dunne (2010) and Dronkers, van der Velden \& Dunne (2011) we expect that parental education and scholastic ability has substantially larger effect on the language score in the third year in school-types in which the allocation and selection have not yet been finished.

\section{Hypotheses}

In stratified educational systems pupils will be allocated to various hierarchically ordered school types at the start of secondary education. However, the base of this allocation might be different in various stratified systems. On the one hand this allocation might be based upon the wishes of parents and their ability to convince the authorities of the receiving secondary school to accept their child as a pupil. Voluntary tests, non-standardized school-grades and non-binding teacher's recommendation might be instruments for the parents in this process of convincing educational authorities. On the other hand this allocation might be only based on earlier educational performance in primary education, as measured by obligatory, standardized tests and obligatory teacher's recommendation. Korthals (2013) shows that the social inequality in educational performance is much weaker in stratified systems in which this allocation is based on educational performance instead of other criteria, like parental preferences. Dollmann (2011) found in a quasi-experimental design in Germany that if parents have the right to persuade schools to accept their child into the highest tracks while there is no exit test and the teacher's recommendation is only optional social inequality was higher than if an objective test and teacher's recommendation were obligatory. The allocation in stratified system of the Netherlands fits the latter situation: an objective test and teacher's recommendation were obligatory for admission into the higher school types and educational authorities use them to control admission to their schools. On the other hand, freedom of school choice allows Dutch parents to seek admission to schools where ever they want (Dijkstra, Dronkers \& Karsten, 2004). The resulting 'pupil-market' might lead to variation in the strictness of the use of the objective test and teacher's recommendation. Therefore our first hypothesis, based on Dunne (2010) and Dronkers, van der Velden \& Dunne (2011), is that in a stratified educational system like the Dutch one scholastic ability and teacher's recommendation predicts better the admission to school-types than parental background.

Different curricula are being taught in these different school types. Given that allocation into these Dutch school-types has mainly be based on scholastic ability and teacher's recommendation (first hypothesis), we expect, based on Korthals (2013), in our second hypothesis that both parental education and socio-economic school composition are not longer significantly related with later performance during secondary education, but that school type has substantial effects due to the different curricula.

As a consequence of the political struggle around the degree of stratification of the Dutch educational systems during the '70s of last century, a number of school-types exists which are less selective because they embrace more than one curriculum. ${ }^{2}$ The most extreme example is the comprehensive school-type, which caters pupils with all levels of scholastic ability and offers a very broad curriculum (like their example the Swedish comprehensive school).

2 This is also true for various German states, in which more selective and less selective school-types exists next to each other as the unintended result of the political struggle around the degree of stratification in education (Prokic-Breuer \& Dronkers, 2012). 
Bridge-classes in the first stages of secondary education were also introduced in the '70s as another main for a better allocation. Bridges-classes combines more than one school-type and thus still offers the possibility of allocation into one of these school types. The most extreme type of bridge-classes are those which combine lower vocational and lower general curricula and those which combine lower, middle and grammar general education. The less extreme type of bridge classes combine to neighboring school-types, like lower and middle general curricula or middle and grammar curricula. Next to the combined bridge-classes there also exits in the first stage of secondary education classes with only one curriculum level. The allocation into the comprehensive school but also in the extreme bridge-classes is not yet completed, while the allocation into the classes with only one curriculum has been completed. This difference in completeness of the allocation can so mean that the range of scholastic ability and parental background is relatively larger in school-types in which the allocation is not yet completed. Our third hypothesis, based on Dunne (2010) and Dronkers, van der Velden \& Dunne (2011), is therefore that parental education and scholastic ability has substantially larger effect on the language score in the third year in school-types in which the allocation and selection have not yet been finished. Another consequence of this difference in the level of completeness of the allocation in the different school-types, based on Dunne (2010) and Dronkers, van der Velden \& Dunne (2011), is that the relation between parental education and early scholastic ability would be stronger in the less selective school types en weaker in the more selective school types (fourth hypothesis).

\section{Data}

Data from the VOCL'89 cohort (a group of pupils entering secondary education in1989 at the age of 12 years) has been used in this note. This cohort is a stratified sample of all pupils in the first year of secondary education in 1989. The Central Statistical Office has made an analysis file available for the purposes of scientific analysis. These pupils took the national primary school-leavers examination, which includes sections on language, arithmetic and general knowledge. We know also the recommendation of the primary school about the most suitable school type of secondary education for each pupil. Both elements (an objective test score and a recommendation) are necessary in the allocation process at the start of secondary education. Only those pupils who were in the first year of secondary education for the first time in 1989 and born in the Netherlands were included in the analysis file (15,747 pupils).

The use the following variables (see tables $1 \& 2$ ):

- Parental education: the mean of fathers and mothers education.

- Scholastic ability: the CITO-score of pupils (national 'end of primary school' test) in $1988 / 1989$, measured before entrance of secondary education as a part of the official transition procedure from primary to secondary education.

- Recommendation by the principal of the basic school about the most suitable school type for the pupils in 1988/189, given before entrance of secondary education as a part of the official transition procedure from primary to secondary education.

- School type in first year secondary education (1989/1990). Parents are not free to choose any school type. Allocation and admission is mainly based on the scholastic ability score (CITO-score) and recommendation, although schools might vary in the strictness of their admission policies.

- Secondary school unit in 1989/1990. Note that some secondary school units contain only one school type (so-called categorical schools), while other secondary school units can contain many different school types (see table 2). The later school units might have more or less mixed first year classes ("bridge-year") while other school units have already homogenous first year classes.

- Average parental education per secondary school unit in 1989/1990. 
- Average ability per secondary school unit in 1989/1990.

- School type in second year secondary education (1990/1991). This was known for all pupils, irrespectively whether they had left the participating school.

- Secondary school unit in 1990/1991. Note that some secondary school units contain only one school type (so-called categorical schools), while other secondary school units can contain many different school types (see table 2). The later school units might have still more or less mixed second year classes, although they tend to be more homogenized than in the first year. Other school units have already homogenous second year classes.

- Participation in Language test in third year of secondary school (1992/1993). About the half of all pupils made that test, because the test was only administered in the schools that participated in the panel. Non-participation in the third year test might thus been caused by a movement to another school (dropout; parental geographical mobility), repeating classes (quite common in the Netherlands) or absence on the day of the test. Downward or upward movements within the participating schools cannot be the cause of non-participation of the test.

- Language score in third year of secondary school (1992/1993).

Table 1: descriptive statistics

\begin{tabular}{|l|r|r|r|r|r|}
\hline & \multicolumn{1}{|c|}{$\mathrm{N}$} & Minimum & Maximum & Mean & Std. Deviation \\
\hline Parent education & 15746 & 101,0 & 146,0 & 118,4 & 11,8 \\
\hline Scholastic ability pupil & 15010 & 4 & 60 & 34,8 & 11,2 \\
\hline Average ability secondary school & 15605 & 13,1 & 53,1 & 34,6 & 8,2 \\
\hline Average parental education secondary school & 15835 & 105,1 & 140,0 & 118,4 & 6,2 \\
\hline Language score third year & 9434 & 0 & 36 & 20,0 & 6,1 \\
\hline
\end{tabular}

Source; VOCL 89; own computation.

Table 2: Pupils recommendation and position in first and second year by school type in $\%$.

\begin{tabular}{|l|r|r|r|}
\hline & Recommendation & $\begin{array}{l}\text { First year } \\
1989-1990\end{array}$ & $\begin{array}{l}\text { Second } \\
\text { year 1990- } \\
1991\end{array}$ \\
\hline Lower vocational (lbo) & 23,2 & 22,2 & 22,9 \\
\hline Lower general (mavo) & 29,1 & 24,1 & 32,7 \\
\hline Middle general (havo) & 12,0 & - & 5,7 \\
\hline Grammar school (vwo) & 6,0 & 2,7 & 8,6 \\
\hline Lower vocational \& general (lbo-mavo) & 6,3 & 6,5 & 4,3 \\
\hline Lower \& middle general (mavo-havo) & 8,5 & 4,3 & 2,5 \\
\hline Lower, middle general \& grammar (mavo-havo-vwo) & - & 15,5 & 3,9 \\
\hline Middle general \& grammar (havo-vwo) & 9,5 & 18,0 & 15,1 \\
\hline Comprehensive (vocational \& general of various levels) & - & 3,2 & 2,6 \\
\hline Individual technical (ibo) & 5,5 & 3,4 & 2,7 \\
\hline N & 15376 & 15726 & 14746 \\
\hline
\end{tabular}

Source; VOCL 89; own computation.

\section{Results}

Correlations between scholastic ability and parental background.

In this section I want to establish whether the relation between parental education and early scholastic ability differs in more or less selective school types. Table 3 gives various (partial) correlations between scholastic ability and parental background by school-composition or by school type.

As to be expected the correlation between scholastic ability and parental background is high (.40). But it declines substantially if we control for school-composition to around .11. 
This means that the strength of the overall correlation between scholastic ability and parental background is lower within schools with the same school composition.

The second part of table 3 shows that the school types in which the selection into different curriculum levels has not yet been completed (comprehensive school which includes both vocational and general of various levels; Lower, middle general \& grammar; Lower vocational \& general) have the highest correlation between scholastic ability and parental background, both in the first and second year. School types in which the selection into different curriculum levels has more or less been completed (Lower general; Middle general; grammar; middle general \& higher) have the lowest correlation between scholastic ability and parental background, both in the first and second year.

These support the fourth hypothesis which assumes that the relation between parental education and early scholastic ability would be stronger in the less selective school types en weaker in the more selective school types.

Table 3: (Partial) correlation between scholastic ability and parental background by schoolcomposition or by school type

\begin{tabular}{|l|r|r|}
\hline Correlation & \multicolumn{2}{|c|}{$.398^{*}$} \\
\hline Partial correlation: control average ability school & \multicolumn{2}{|c|}{$.117^{*}$} \\
\hline Partial correlation: control average parental education school & \multicolumn{2}{|c|}{$.107^{*}$} \\
\hline Partial correlation: control average ability \& parental education school & \multicolumn{2}{|c|}{$.123^{*}$} \\
\hline & $1989-1990$ & $1990-1991$ \\
\hline Correlation Lower vocational (lbo) & $.150^{*}$ & $.126^{*}$ \\
\hline Correlation Lower general (mavo) & $.071^{*}$ & $.082^{*}$ \\
\hline Correlation Middle general (havo) & - & .008 \\
\hline Correlation Grammar school (vwo) & .095 & $.092^{*}$ \\
\hline Correlation Lower vocational \& general (lbo-mavo) & $.167^{*}$ & $.238^{*}$ \\
\hline Correlation Lower \& middle general (mavo-havo) & $.115^{*}$ & .108 \\
\hline Correlation Lower, middle general \& grammar (mavo-havo-vwo) & $.213^{*}$ & $.159^{*}$ \\
\hline Correlation Middle general \& grammar (havo-vwo) & $.065^{*}$ & $.064^{*}$ \\
\hline Correlation Comprehensive (vocational \& general of various levels) & $.190^{*}$ & $.246^{*}$ \\
\hline Correlation Individual technical & $.132^{*}$ & .008 \\
\hline
\end{tabular}

Source; VOCL 89; own computation; * significant $\mathrm{p}<.05$.

\section{Allocation into a secondary school-type}

In this section I want to establish whether the strength of the effect of parental education on getting a recommendation for a school type and on attending a school type in the first or second year is larger than the strength of early scholastic ability. The first two columns of table 4 gives the results of three multinominal logistic regressions with the school types as dependent variables (recommendation; first year; second year) and parental education and scholastic ability as covariates. Grammar school is the reference category. Because I show the exponent of $\mathrm{B}$, we can compare more easily the results. Both parameters of parental education and scholastic ability are significant, but the strength of the parameter of scholastic ability in all cases much stronger than that of parental education. The variance of both parameters is largest for the scholastic ability parameter, which reflects the cognitive aspect of the allocation in various school types. The variance in the parental education parameter is much smaller and it is most visible for the allocation into grammar school.

These results support the first hypothesis, which would expect that the strength of parental education is substantially smaller than that of early scholastic ability in highly differentiated educational systems. This also underlines the importance of including early ability in order to estimate correctly the strength of parental background in the allocation process into school types. The last column of table 4 gives the result if parental education is 
the only covariate. The strength of the parameters of parental education in the third column is stronger than those in the first column. Moreover, the fit of the equation without scholastic ability is substantial lower than the fit of the equation with both parental education and scholastic ability. This also shows that scholastic ability is the most important predictor of the allocation into the different school types.

Table 4: Pupils recommendation and position by school type in first and second year, predicted by parental education and scholastic ability together and by parental education only (6 multinominal logistic regressions; $\operatorname{Exp}(\mathrm{B})$ ).

\begin{tabular}{|c|c|c|c|}
\hline & \multicolumn{2}{|c|}{ Combined } & \multirow{2}{*}{$\begin{array}{l}\text { Only } \\
\text { Parental } \\
\text { education }\end{array}$} \\
\hline Recommendation & $\begin{array}{l}\text { Parental } \\
\text { education }\end{array}$ & $\begin{array}{l}\text { Scholastic } \\
\text { ability }\end{array}$ & \\
\hline Lower vocational (lbo) & .884 & .620 & .861 \\
\hline Lower general (mavo) & .923 & .698 & .910 \\
\hline Middle general (havo) & .956 & .834 & 951 \\
\hline Grammar school (vwo) & Ref. & Ref. & Ref. \\
\hline Lower vocational \& general (lbo-mavo) & .906 & .653 & .889 \\
\hline Lower \& middle general (mavo-havo) & .942 & .765 & .933 \\
\hline Middle general \& grammar (havo-vwo) & .971 & .910 & .969 \\
\hline Individual technical (ibo) & .877 & .513 & .836 \\
\hline \multicolumn{4}{|l|}{ First year 1989-1990 } \\
\hline Lower vocational (lbo) & .860 & .679 & .831 \\
\hline Lower general (mavo) & .896 & .746 & 877 \\
\hline Grammar school (vwo) & Ref. & Ref. & Ref. \\
\hline Lower vocational \& general (lbo-mavo) & .873 & .696 & .846 \\
\hline Lower \& middle general (mavo-havo) & .916 & .778 & .899 \\
\hline Lower, middle general \& grammar (mavo-havo-vwo) & .920 & .818 & .908 \\
\hline Middle general \& grammar (havo-vwo) & .942 & .909 & .936 \\
\hline Comprehensive (vocational \& general of various levels) & .900 & .721 & .878 \\
\hline Individual technical (ibo) & .853 & .561 & .804 \\
\hline \multicolumn{4}{|l|}{ Second year 1990-1991 } \\
\hline Lower vocational (lbo) & .884 & 677 & 863 \\
\hline Lower general (mavo) & .927 & .748 & .914 \\
\hline Middle general (havo) & .962 & .854 & .956 \\
\hline Grammar school (vwo) & Ref. & Ref. & Ref. \\
\hline Lower vocational \& general (lbo-mavo) & .907 & .686 & .885 \\
\hline Lower \& middle general (mavo-havo) & .930 & .782 & .924 \\
\hline Lower, middle general \& grammar (mavo-havo-vwo) & .931 & .793 & ,922 \\
\hline Middle general \& grammar (havo-vwo) & .974 & 907 & .969 \\
\hline Comprehensive (vocational \& general of various levels) & .935 & .696 & .915 \\
\hline Individual technical (ibo) & .872 & .564 & .833 \\
\hline Log likelihood & \multicolumn{2}{|c|}{22122} & 3759 \\
\hline Nagelkerke R2 & \multicolumn{2}{|c|}{.549} & .213 \\
\hline
\end{tabular}

Source; VOCL 89; own computation; all parameters significant.

Attaining the third year in time and participating in the test.

As said earlier, the Dutch language test in the third year was taken by a substantial smaller number of students. Table 5 analyzes the participation. Participation is not driven my parental education or the socio-economic school composition, based on parental education. Scholastic ability is the best predictor, together with school type in the second year. The non-participation is highest in the school types in which selection has not been completed (lower vocational \& general; lower, middle general \& grammar 
school and comprehensive). An explanation might be that students in these school types have a higher probability to move to another school and thus not participate in the test in the third year. The negative parameter of ability school composition on participation in the third years test might be explained by a higher plausibility of dropping out by a student in a more challenging environment.

But the most important point is that table 5 shows that an analysis of the Dutch language scores in the third year will not be too strongly biased.

Table 5: Multi-level logistic regression with participation in Dutch language score in third year as dependent variable (N pupils=15835; N schools 1990/1991=10833).

\begin{tabular}{|c|c|c|c|c|c|}
\hline & Model 1 & Model 2 & Model 3 & Model 4 & Model 5 \\
\hline Parental education & $\begin{array}{l}0.003 \\
(0.002)\end{array}$ & $\begin{array}{l}0.001 \\
(0.002)\end{array}$ & $\begin{array}{l}0.003 \\
(0.002)\end{array}$ & $\begin{array}{l}0.003 \\
(0.002)\end{array}$ & $\begin{array}{l}0.002 \\
(0.002)\end{array}$ \\
\hline Scholastic ability & & $\begin{array}{l}0.023^{*} \\
(0.002)\end{array}$ & $\begin{array}{l}0.031^{*} \\
(0.002)\end{array}$ & $\begin{array}{l}0.031 * \\
(0.002)\end{array}$ & $\begin{array}{l}0.029^{*} \\
(0.003)\end{array}$ \\
\hline Average ability secondary school & & & $\begin{array}{l}-0.063^{*} \\
(0.006)\end{array}$ & $\begin{array}{l}-0.066^{*} \\
(0.011)\end{array}$ & $\begin{array}{l}-0.062^{*} \\
(0.013)\end{array}$ \\
\hline $\begin{array}{l}\text { Average parental education } \\
\text { secondary school }\end{array}$ & & & & $\begin{array}{l}0.004 \\
(0.014)\end{array}$ & $\begin{array}{l}-0.017 \\
(0.016)\end{array}$ \\
\hline Grammar school & & & & & Ref. \\
\hline Lower vocational & & & & & $\begin{array}{l}-0.500^{*} \\
(0.188)\end{array}$ \\
\hline Lower general & & & & & $\begin{array}{l}-0.190 \\
(0.137)\end{array}$ \\
\hline Middle general & & & & & $\begin{array}{l}-0.040 \\
(0.109) \\
\end{array}$ \\
\hline Lower vocational \& general & & & & & $\begin{array}{l}-1.084^{*} \\
(0.257)\end{array}$ \\
\hline Lower \& Middle general & & & & & $\begin{array}{l}-0.459 \\
(0.278)\end{array}$ \\
\hline Lower, middle general \& grammar & & & & & $\begin{array}{l}-1.899^{*} \\
(0.268)\end{array}$ \\
\hline Middle \& Grammar & & & & & $\begin{array}{l}-0.284 \\
(0.172)\end{array}$ \\
\hline Comprehensive & & & & & $\begin{array}{l}-0.962^{*} \\
(0.419) \\
\end{array}$ \\
\hline Individual vocational & & & & & $\begin{array}{l}-0.182 \\
(0.244)\end{array}$ \\
\hline School level variance & $1.66(0.11)$ & $1.77(0.11)$ & $1.63(0.11)$ & $1.63(0.11)$ & $1.79(0.12)$ \\
\hline
\end{tabular}

Source; VOCL 89; own computation; * significant p<.05; school type 1990/91; grammar school reference category.

\section{Dutch language score in third year as dependent variable}

In this section I want to establish whether parental education and socio-economic school composition are still related to the language score in the third year (pupils are around 15 years old, just like the pupils in PISA, and this test is comparable to a PISA performance test). Table 6 shows clearly that early scholastic ability is the best predictor of the Dutch language score, followed by school type. The addition of these variables to the equation improves the model fit (log likelihood) most (Model 1 versus 2; model 3 versus 4). Parental education remains significant in all models, but its strength declines strongly after addition of scholastic ability. Socio-economic school composition has no effect in any of the models. These results support partly the second hypothesis that both parental education and socio-

\footnotetext{
3 The number of school units is much larger than the number of schools in the sample due to movements of pupils to schools outside the sample during the first three years of secondary education.
} 
economic school composition are not longer significantly related with the performance score, but that school type has substantial effects.

The model 5 of table 6 is another support of the second hypothesis. We add the interactions between parental education and school types. The first result is that the main effect of parental education becomes insignificant, while some interactions between school types and parental education become significantly positive. At the same time the effect of early scholastic ability remains unchanged positive and significant. This support the assumption that the selection into different Dutch school types mainly based on scholastic ability and teacher's recommendation is the explanation of the overall higher effects of SES on educational performance in differentiated systems. The second result is the nature of the school types, which have significant and positive interactions between school types and parental education. These are only those school types, in which the selection into various tracks is not yet completed: Lower vocational \& general; Lower, middle general \& grammar; Comprehensive. There are only significant effects of parental education on the language score in the third year in these more undifferentiated school types, while there is no effect of parental education in the other more differentiated school types. This support the third hypothesis that assumes that SES is only significant within school types without ability selection, while it is insignificant within school types with ability selection.

Model 6 add the interactions between early scholastic ability and school types. The main effect of scholastic ability remains significant and substantial, while two interactions between school types and scholastic ability become significantly positive (Lower, middle general \& grammar; Comprehensive) and one becomes negative (Middle general). The other interactions are insignificant. This support the third hypothesis because it shows that only in the least selective school types (Lower, middle general \& grammar; Comprehensive) early ability still influences performance.

We also estimated a model with all interactions between school types and parental background combined. The results are given in table 7 , in which we also group the school types based on the completeness of the selection into that school type. We still find that early ability is strongest in the least selective school types (Lower, middle general \& grammar; Comprehensive), but also that the effect of parental education is strongest in some of the less selective school types (Lower vocational \& general; Lower, middle general \& grammar; Lower \& middle general). Combining both groups of interactions does not change the earlier support of our hypotheses, because it shows that only in the least selective school types early ability and parental background influence performance most strongly.

Table 8 shows the expected scores on Dutch language test in third year in school types with completed or not yet completed selection of pupils with average ability and average parental background or high ability and low parental background or high ability and low parental background. These estimations show clearly that the educational performance (measured as scores on a Dutch language test) is lowest at school-types with not yet completed selection for pupils with the same ability and parental background. They also show that pupils with high ability and low parental background do not perform better at schooltypes with not yet completed selection, which suggests that smart pupils from low social background do not profit more from non-selective school-types. 
Table 6: Multi-level OLS regression with Dutch language score in third year as dependent variable (N pupils=9387; N schools 1990/1991=324).

\begin{tabular}{|c|c|c|c|c|c|c|}
\hline & Model 1 & Model 2 & Model 3 & Model 4 & Model 5 & Model 6 \\
\hline Parental education & $\begin{array}{l}0.054 * \\
(0.005)\end{array}$ & $\begin{array}{c}0.025^{*} \\
(0.005) \\
\end{array}$ & $\begin{array}{l}0.020 * \\
(0.005)\end{array}$ & $\begin{array}{l}0.013 * \\
(0.005) \\
\end{array}$ & $\begin{array}{l}-0.013 \\
(0.013)\end{array}$ & $\begin{array}{l}0.012 * \\
(0.005)\end{array}$ \\
\hline Scholastic ability & & $\begin{array}{l}0.305 * \\
(0.006)\end{array}$ & $\begin{array}{l}0.288 * \\
(0.006)\end{array}$ & $\begin{array}{l}0.254 * \\
(0.007)\end{array}$ & $\begin{array}{l}0.253^{*} \\
(0.007)\end{array}$ & $\begin{array}{l}0.282^{*} \\
(0.030)\end{array}$ \\
\hline $\begin{array}{l}\text { Average ability secondary } \\
\text { school }\end{array}$ & & & $\begin{array}{l}0.087 * \\
(0.023)\end{array}$ & $\begin{array}{l}0.006 \\
(0.026)\end{array}$ & $\begin{array}{l}0.006 \\
(0.026)\end{array}$ & $\begin{array}{l}0.008 \\
(0.026)\end{array}$ \\
\hline $\begin{array}{l}\text { Average parental education } \\
\text { secondary school }\end{array}$ & & & $\begin{array}{l}0.037 \\
(0.030)\end{array}$ & $\begin{array}{l}-0.031 \\
(0.031)\end{array}$ & $\begin{array}{l}-0.030 \\
(0.031)\end{array}$ & $\begin{array}{l}-0.033 \\
(0.030)\end{array}$ \\
\hline Grammar school & & & & Ref. & Ref. & Ref. \\
\hline Lower vocational & & & & $\begin{array}{l}-5.30 * \\
(0.40)\end{array}$ & $\begin{array}{l}-7.82 * \\
(2.18)\end{array}$ & $\begin{array}{l}-2.95 \\
(1.56)\end{array}$ \\
\hline Lower general & & & & $\begin{array}{l}-3.27 * \\
(0.27) \\
\end{array}$ & $\begin{array}{l}-6.69 * \\
(1.97) \\
\end{array}$ & $\begin{array}{l}-1.56 \\
(1.56)\end{array}$ \\
\hline Middle general & & & & $\begin{array}{l}-2.79 * \\
(0.27) \\
\end{array}$ & $\begin{array}{l}-6.59^{*} \\
(2.68)\end{array}$ & $1.07(1.98)$ \\
\hline Lower vocational \& general & & & & $\begin{array}{l}-3.53 * \\
(0.52)\end{array}$ & $\begin{array}{l}-10.99 * \\
(3.09)\end{array}$ & $\begin{array}{l}-3.45 \\
(1.79)\end{array}$ \\
\hline Lower \& Middle general & & & & $\begin{array}{l}-2.57 * \\
(0.58) \\
\end{array}$ & $\begin{array}{l}-7.96 \\
(4.65) \\
\end{array}$ & $\begin{array}{l}-2.39 \\
(2.53) \\
\end{array}$ \\
\hline $\begin{array}{l}\text { Lower, middle general \& } \\
\text { grammar }\end{array}$ & & & & $\begin{array}{l}-2.68 * \\
(0.61) \\
\end{array}$ & $\begin{array}{l}-10.83 * \\
(3.61)\end{array}$ & $\begin{array}{l}-6.11^{*} \\
(2.15) \\
\end{array}$ \\
\hline Middle \& Grammar & & & & $\begin{array}{l}-1.35^{*} \\
(0.32)\end{array}$ & $\begin{array}{l}-4.49 * \\
(2.19)\end{array}$ & $\begin{array}{l}-0.68 \\
(1.75)\end{array}$ \\
\hline Comprehensive & & & & $\begin{array}{l}-3.58^{*} \\
(0.73) \\
\end{array}$ & $\begin{array}{l}-11.51 * \\
(3.63)\end{array}$ & $\begin{array}{l}-6.07 * \\
(1.87) \\
\end{array}$ \\
\hline Individual vocational & & & & $\begin{array}{l}-6.27 * \\
(0.53) \\
\end{array}$ & $\begin{array}{l}-7.36 \\
(4.23) \\
\end{array}$ & $\begin{array}{l}-3.59 \\
(1.82) \\
\end{array}$ \\
\hline \multicolumn{7}{|c|}{ Interaction with parental education (model 5) or early scholastic ability (model 6) } \\
\hline Lower vocational & & & & & $\begin{array}{l}0.019 \\
(0.018)\end{array}$ & $\begin{array}{l}-0.063 \\
(0.033)\end{array}$ \\
\hline Lower general & & & & & $\begin{array}{l}0.027 \\
(0.016)\end{array}$ & $\begin{array}{l}-0.038 \\
(0.032)\end{array}$ \\
\hline Middle general & & & & & $\begin{array}{l}0.030 \\
(0.021)\end{array}$ & $\begin{array}{l}-0.086^{*} \\
(0.043)\end{array}$ \\
\hline Lower vocational \& general & & & & & $\begin{array}{l}0.062 * \\
(0.026)\end{array}$ & $\begin{array}{l}0.017 \\
(0.042) \\
\end{array}$ \\
\hline Lower \& Middle general & & & & & $\begin{array}{l}0.044 \\
(0.039)\end{array}$ & $\begin{array}{l}(0.006) \\
(0.060)\end{array}$ \\
\hline $\begin{array}{l}\text { Lower, middle general \& } \\
\text { grammar }\end{array}$ & & & & & $\begin{array}{l}0.068^{*} \\
(0.030)\end{array}$ & $\begin{array}{l}0.097 * \\
(0.047)\end{array}$ \\
\hline Middle \& Grammar & & & & & $\begin{array}{l}0.024 \\
(0.017)\end{array}$ & $\begin{array}{l}-0.012 \\
(0.036)\end{array}$ \\
\hline Comprehensive & & & & & $\begin{array}{l}0.064^{*} \\
(0.029)\end{array}$ & $\begin{array}{l}0.103 * \\
(0.042)\end{array}$ \\
\hline Individual vocational & & & & & $\begin{array}{l}0.006 \\
(0.037) \\
\end{array}$ & $\begin{array}{l}-0.103 \\
(0.062) \\
\end{array}$ \\
\hline Pupil level variance & $\begin{array}{l}23.05 \\
(0.34)\end{array}$ & $\begin{array}{l}18.50 \\
(0.28)\end{array}$ & $\begin{array}{l}18.46 \\
(0.28)\end{array}$ & $\begin{array}{l}18.23 \\
(0.24)\end{array}$ & $\begin{array}{l}18.21 \\
(0.28)\end{array}$ & $\begin{array}{l}18.14 \\
(0.24)\end{array}$ \\
\hline School level variance & $\begin{array}{l}11.53 \\
(1.02)\end{array}$ & $2.88(0.30)$ & $\begin{array}{l}2.35 \\
(0.26)\end{array}$ & $\begin{array}{l}2.08 \\
(0.24)\end{array}$ & $\begin{array}{l}2.07 \\
(0.24)\end{array}$ & $\begin{array}{l}18.14 \\
(0.28)\end{array}$ \\
\hline log likelihood & 56893 & 52545 & 52488 & 49338 & 49326 & 49288 \\
\hline
\end{tabular}

Source; VOCL 89; own computation; * significant $\mathrm{p}<.05$; school type 1990/91 
Table 7: Variations in effects of parental education and scholastic ability on Dutch language score in third year between school types with completed or not yet completed selection with all interactions of school-types*ability and school-types*parental education simultaneously (in contrast to models $5 \& 6$ of table 6 ).

\begin{tabular}{|l|l|l|l|l|l|l|l|l|}
\hline $\begin{array}{l}\text { Completed } \\
\text { selection }\end{array}$ & $\begin{array}{l}\text { Parental } \\
\text { education }\end{array}$ & Ability & $\begin{array}{l}\text { Half-way } \\
\text { completed } \\
\text { selection }\end{array}$ & $\begin{array}{l}\text { Parental } \\
\text { education }\end{array}$ & Ability & $\begin{array}{l}\text { Not yet } \\
\text { completed } \\
\text { selection }\end{array}$ & $\begin{array}{l}\text { Parental } \\
\text { education }\end{array}$ & Ability \\
\hline $\begin{array}{l}\text { Grammar } \\
\text { school }\end{array}$ & -0.013 & $0.284 \dagger$ & $\begin{array}{l}\text { Lower \& } \\
\text { middle } \\
\text { general }\end{array}$ & 0.032 & 0.291 & $\begin{array}{l}\text { Lower } \\
\text { vocational \& } \\
\text { general }\end{array}$ & $0.043^{*}$ & 0.288 \\
\hline $\begin{array}{l}\text { Middle } \\
\text { general }\end{array}$ & 0.017 & $0.196^{*}$ & $\begin{array}{l}\text { Middle \& } \\
\text { Grammar }\end{array}$ & 0.011 & 0.271 & $\begin{array}{l}\text { Lower, middle } \\
\text { \& grammar }\end{array}$ & $0.042^{*}$ & $0.367^{*}$ \\
\hline $\begin{array}{l}\text { Lower } \\
\text { general }\end{array}$ & 0.014 & 0.224 & & & & Comprehensive & 0.018 & $0.384^{*}$ \\
\hline $\begin{array}{l}\text { Lower } \\
\text { vocational }\end{array}$ & 0.009 & $0.220^{*}$ & & & & & & \\
\hline $\begin{array}{l}\text { Individual } \\
\text { vocational }\end{array}$ & 0.087 & 0.182 & & & & & & \\
\hline
\end{tabular}

Source; VOCL 89; own computation; † term significant $(\mathrm{p}<.05) *$ interaction-term school-type X Parental education or ability significant $(\mathrm{p}<.05)$; school type 1990/91 
Table 8: Expected scores on Dutch language test in third year in school types with completed or not yet completed selection of pupils with average ability and average parental background or high ability and low parental background or high ability and high parental background (based on table 7).

\begin{tabular}{|c|c|c|c|c|c|}
\hline Completed selection & & Half-way completed selection & & Not yet completed selection & \\
\hline \multicolumn{6}{|c|}{ Pupil with average ability \& parental education } \\
\hline Grammar school & 23.3 & Lower \& middle general & 15.5 & Lower vocational \& general & 13.4 \\
\hline Middle general & 20.6 & Middle \& Grammar & 22.5 & Lower, middle \& grammar & 10.8 \\
\hline Lower general & 18.4 & & & Comprehensive & 13.5 \\
\hline Lower vocational & 17.6 & & & & \\
\hline Individual vocational & 18.2 & & & & \\
\hline \multicolumn{6}{|c|}{ Pupil with high ability (+1 SD) \& low parental education (-1 SD) } \\
\hline Grammar school & 26.4 & Lower \& middle general & 18.1 & Lower vocational \& general & 15.9 \\
\hline Middle general & 22.3 & Middle \& Grammar & 25.5 & Lower, middle \& grammar & 14.2 \\
\hline Lower general & 20.7 & & & Comprehensive & 14.1 \\
\hline Lower vocational & 19.7 & & & & \\
\hline Individual vocational & 20.1 & & & & \\
\hline \multicolumn{6}{|c|}{ Pupil with high ability (+1 SD) \& high parental education (+1 SD) } \\
\hline Grammar school & 26.6 & Lower \& middle general & 19.3 & Lower vocational \& general & 17.5 \\
\hline Middle general & 23.3 & Middle \& Grammar & 25.7 & Lower, middle \& grammar & 15.8 \\
\hline Lower general & 21.5 & & & Comprehensive & 18.3 \\
\hline Lower vocational & 20.5 & & & & \\
\hline Individual vocational & 20.8 & & & & \\
\hline \multicolumn{6}{|c|}{ Pupil with low ability (-1 SD) \& high parental education (+1 SD) } \\
\hline Grammar school & 20.2 & Lower \& middle general & 12.9 & Lower vocational \& general & 10.9 \\
\hline Middle general & 18.9 & Middle \& Grammar & 19.3 & Lower, middle \& grammar & 7.4 \\
\hline Lower general & 15.1 & & & Comprehensive & 9.7 \\
\hline Lower vocational & 14.1 & & & & \\
\hline Individual vocational & 14.1 & & & & \\
\hline \multicolumn{6}{|c|}{ Pupil with low ability (-1 SD) \& low parental education (-1 SD) } \\
\hline Grammar school & 20.0 & Lower \& middle general & 11.7 & Lower vocational \& general & 9.3 \\
\hline Middle general & 15.9 & Middle \& Grammar & 19.1 & Lower, middle \& grammar & 5.8 \\
\hline Lower general & 14.3 & & & Comprehensive & 8.7 \\
\hline Lower vocational & 13.3 & & & & \\
\hline Individual vocational & 13.7 & & & & \\
\hline
\end{tabular}

Source; VOCL 89; own computation;

\section{Conclusion}

In this research note I analyze the Dutch longitudinal data (VOCL 1989), which contains a measurement of scholastic ability of the pupils before entering secondary education, the SESand ability school-composition of all secondary schools, and various school-types in the first years of Dutch secondary education, running from non-selective (comprehensive) to highly selective (Gymnasium).

The analyses show that the relation between parental education and early scholastic ability differs in more or less selective school types: the relation is stronger in the less selective school types (lower vocational \& general; lower, middle general \& grammar; comprehensive) en weaker in the more selective school types (lower general; middle general; grammar; middle general \& grammar; individual technical). The Dronkers, van der Velden \& Dunne would predict this differences in the relation between parental education and early scholastic ability (fourth hypothesis).

I also show that the strength of the effect of parental education on getting a recommendation for a school type and on attending a school type in the first or second year is smaller than the strength of early scholastic ability, as would be predicted by the Dronkers, van der Velden \& Dunne (2011) or Korthals (2012) for stratified educational systems like that 
of the Netherlands, where the allocation across the various school types is mainly based on standardized measurement of scholastic ability at the end of primary education and on obligatory teacher's advice instead of parental preferences (first hypothesis).

I analyze also whether parental education and socio-economic school composition are still related to the language score in the third year (pupils are around 15 years old, just like the pupils in PISA). I found that both parental education and socio-economic school composition are not longer significantly related with the performance score, but that school type has substantial effects on the language score in the third year (second hypothesis).

Finally we found that parental education has still significant effects on the language score in the third year, but only in the less selective school types (Lower vocational \& general; Lower, middle general \& grammar; Comprehensive), while parental education has no effect in the more selective school types (third hypothesis). This last result would also be predicated by Dronkers, van der Velden \& Dunne (2011).

These results show that the results of the three-level model introduced by Dunne (2010), Dronkers, van der Velden \& Dunne (2011) (countries, schools, and students) and Korthals (2012) can be replicated with the inclusion of early scholastic ability. School characteristics like entrance selectivity based on scholastic ability at the end of primary education affect the relations between parental background and early scholastic ability on the one hand and later educational achievement in secondary schools at the other hand. Moreover, school characteristics seem to mediate some of the effects of educational system characteristics, which were found with a two level-model.

A replication of this analysis for Germany might give further support for the Dronkers, van der Velden \& Dunne results. Within Germany, there is a large variety in the school types with more or less completed selection and also a large variety in the importance of early ability and teacher recommendation for the admission to the various school types (ProkicBreuer \& Dronkers, 2012).

\section{References}

Bol, T., Witschge, J., Werfhorst, H.G. van de \& Dronkers, J. (forthcoming). Curricular Tracking and Central Examinations: Counterbalancing the Impact of Social Background on Student Achievement in 36 Countries. Social Forces (in press)

Dijkstra, A., J. Dronkers \& S. Karsten, (2004). "Private Schools as Public Provision for Education: School Choice and market Forces in the Netherlands." pp. 67-90 in Educating Citizens. International Perspectives on Civic Values and School Choice, edited by P. J. Wolf \& S. Macedo. Washington DC: Brookings Institute Press.

Dollmann, J. (2011) Verbindliche und unverbindliche Grundschulempfehlungen und soziale Ungleichheiten am ersten Bildungsübergang. Kölner Zeitschrift für Soziologie und Sozialpsychologie, 63(4): 431-457.

Dronkers, J., Velden, R. van der \& Dunne, A. (2011). The effects of educational systems, school-composition, track-level, parental background and immigrants' origins on the achievement of 15-years-old native and immigrant students. A reanalysis of PISA 2006. ROA Research Memorandum 2011/6, Maastricht University.

Dunne, A. (2010). Dividing Lines: Examining the Relative Importance of betweenand within-School Differentiation during lower Secondary Education. PhD thesis European University Institute (Florence, Italy).

Esser, H. (forthcoming). Bildungssysteme und (ethnische) Bildungsungleichheit. Unpublished paper, Mannheim Centre for European Social Research, University of Mannheim, 2014. 
Hanushek, E. R. \& Wößmann, L. (2006). "Does Educational Tracking Affect Performance and Inequality? Differences- in-Differences Evidence Across Countries," Economic Journal, 116(510), pages C63-C76.

Hanushek, E. R. \& Wößmann, L. (2012). "Do better schools lead to more growth? Cognitive skills, economic outcomes, and causation," Journal of Economic Growth, 17(4), pages 267-321.

Prokic-Breuer, T. \& Dronkers, J. (2012). "The high performance of Dutch and Flemish 15-year-old native pupils: Explaining country differences in math scores between highly stratified educational systems" Educational Research and Evaluation 18: 749-777

Korthals, R. (2012). Selection and tracking in secondary education: A cross country analysis of student performance and educational opportunities, ROA-RM-2012/14, Maastricht University.

Schütz, G., Ursprung, H. \& Wößmann, L. (2008). "Education Policy and Equality of Opportunity," Kyklos, 61(2), pages 279-308.

Wößmann, L., Lüdemann, E., Schütz, G. \& West, M. R. (2009). School Accountability, Autonomy, Choice and the Level of Student Achievement: International Evidence from PISA 2003. OECD Education Working Paper No. 13, Paris: OECD. 


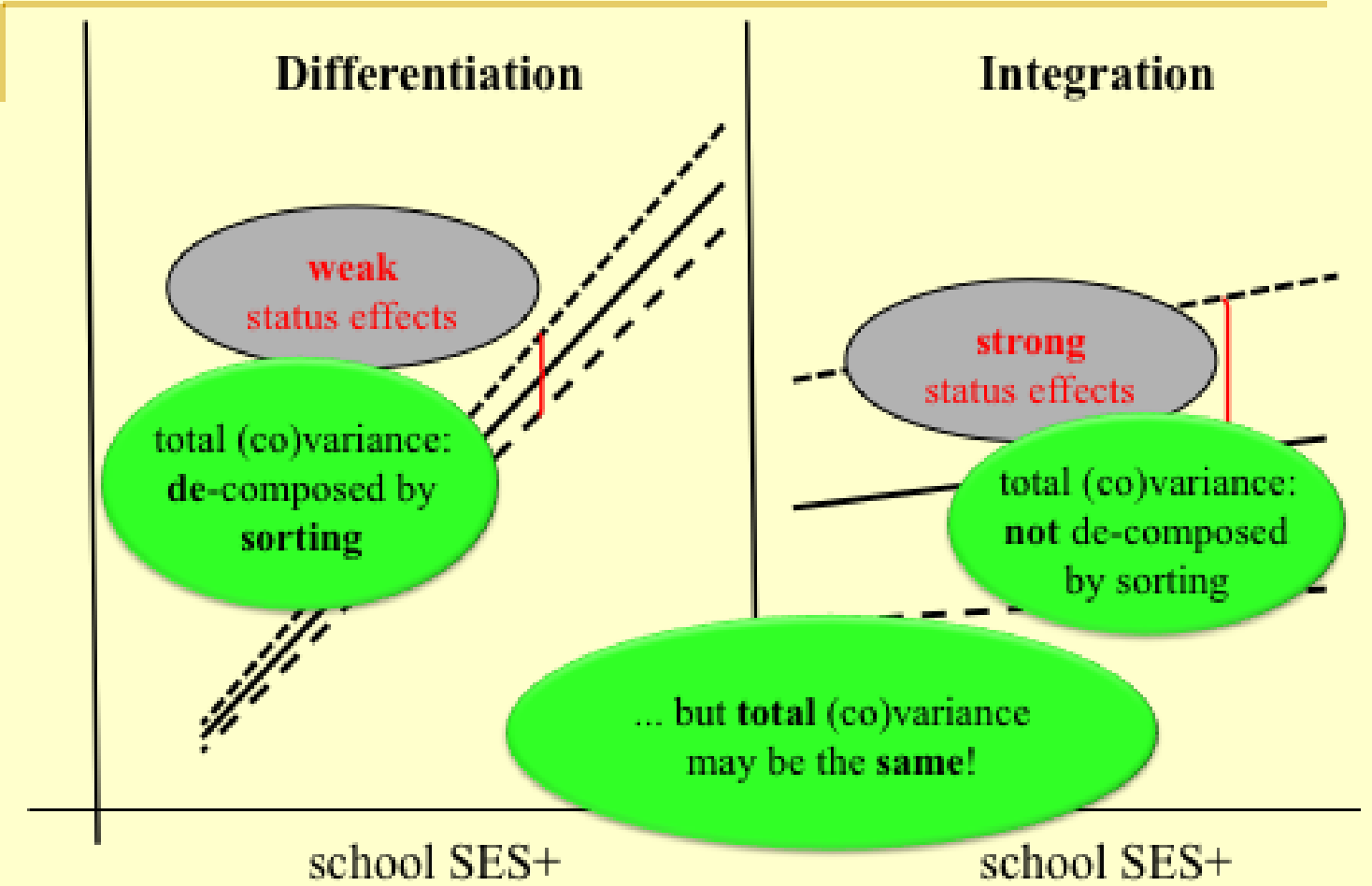

Figure 1: The Dronkers, Velden \& Dunne results as visualized by Esser (fortcoming) 


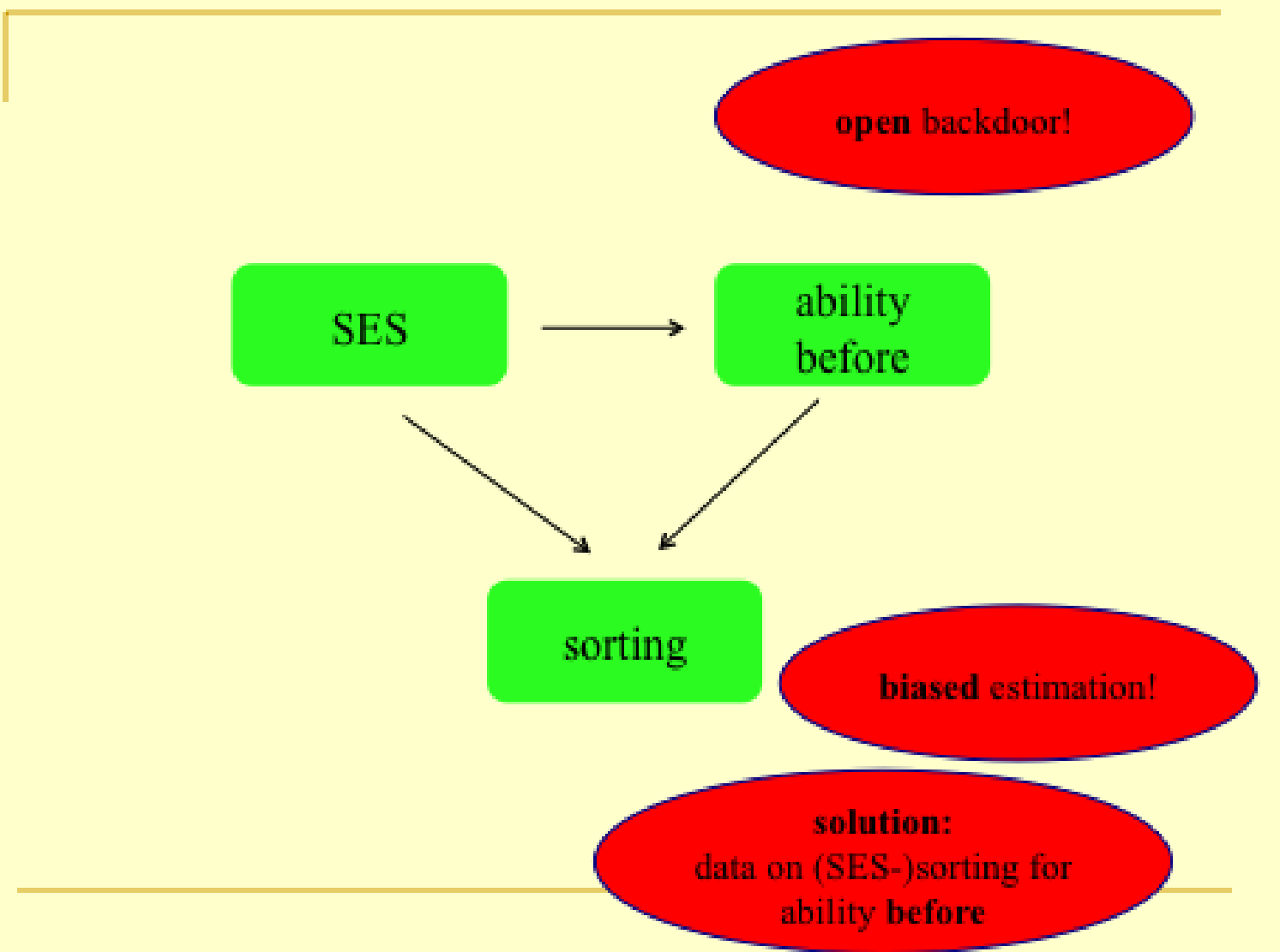

Figure 2: The problem of missing ability before sorting as visualized by Esser (forth coming). 